\title{
Studies on DNA-protein interactions in the upstream regulatory region of the human $\varepsilon$-globin gene promoter ${ }^{1}$
}

\author{
YAN Zhi JiAng, Ya Di CHEN, Ruo LAN QIAN ${ }^{2}$ \\ Shanghai Institute of Cell Biology, Chinese Academy of \\ Sciences, 320 Yueyang Road, Shanghai 200031, China
}

\begin{abstract}
The erythroid- and developmental stage-specific expression of the human $\varepsilon$-globin gene is controlled, in part, by the 5'-flanking DNA sequence of this gene. In the present study, we have used DNA-protein binding assays to identify trans-acting factors which regulate the temporal expression of the human $\varepsilon$-globin gene during development. Using gel mobility shift assays and DNaseI footprinting assays, a nuclear protein factor (termed $\varepsilon$ $\mathrm{SSF} 1$ ) in the nuclear extracts from mouse haematopoietic tissues at $\mathrm{d} 11$ and $\mathrm{d} 13$ of gestation was identified. It could specifically bind to the positive control region (between -535 and $-453 \mathrm{bp}$ ) of the human $\varepsilon$-globin gene. We speculated that the $\varepsilon$-SSF1 might be an erythroid- and developmental stage-specific activator. In addition, we found another nuclear protein factor (termed $\varepsilon-\mathrm{R} 1$ ) in the nuclear extract from mouse fetal liver at d 18 of gestation, which could strongly bind to the silencer region (between -392 and $-177 \mathrm{bp}$ ) of this gene. Therefore, we speculated that the $\varepsilon$-R1 might be an erythroid- and developmental stagespecific repressor. Our data suggest that both $\varepsilon$-SSF1 and $\varepsilon$-R1 might play important roles in developmental regulation of the human $\varepsilon$-globin gene expression during the early embryonic life. On the other hand, we observed that the binding patterns of nuclear proteins from three cell lines (K562, HEL and Raji) to these regulatory regions
\end{abstract}

1. This project was supported by grant from Chinese National Nature Science Foundation

2. To whom correspondence should be addressed. 
DNA-protein interactions in the regulatory regions of human $\varepsilon$-globin gene

were partially different. These results suggest that different trans-acting factors in K562, HEL and Raji cells might be responsible for activating or silencing the human $\varepsilon$-globin gene in three different cell lines.

Key words: Human $\varepsilon$-globin gene, positive control region, silencer, trans-acting factor.

\section{INTRODUCTION}

The human $\beta$ l-like globin gene cluster spans a region of $70 \mathrm{~kb}$ on chromosome 11 and contains five developmentally regulated genes in the order 5 '- $\varepsilon, G_{\Upsilon},{ }_{\Upsilon}, \delta, \beta-3$ '. During human development, the embryonic globin gene $(\varepsilon)$ is the earliest-expressed $\beta$-like globin gene. It is activated in primitive erythrocytes located at the blood island of the yolk sac and is silenced completely at later developmental stages[1]. Studies in transgenic mice or in differentiating embryoid bodies have shown that the erythroid- and developmental stage-specific expression of the human $\varepsilon$-globin gene is controlled, in part, by the 5'-flanking sequence of this gene[2, 3]. A transcriptional silencer (between -392 and $-177 \mathrm{bp}$ ) upstream of the human $\varepsilon$-globin gene has been identified[4]. Deletion of this region results in the continued expression of the human $\varepsilon$-globin gene during late fetal and adult development in transgenic mice, suggesting that in vivo this silencer may play a role in silencing the human $\varepsilon$-globin gene at these later developmental stages[5]. In addition, a positive control region (between-535 and -453bp) upstream of this silencer has been identified[6] (Fig 1). However, little is known about the regulatory mechanism of the human $\varepsilon$-globin gene expression in an erythroid- and developmental stage-specific manner.

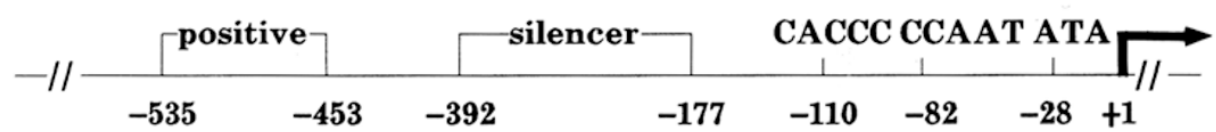

Fig 1. Schematic diagram of the upstream region of the human $\varepsilon$-globin gene. The DNA fragment between -535 and $-453 \mathrm{bp}$ is a positive control region, and the DNA fragment between -392 and $-177 \mathrm{bp}$ is a silencer region.

In this paper, we used gel mobility shift assay and DNaseI footprinting assay to identify trans-acting factors which regulate the temporal expression of the human $\varepsilon$-globin gene during development, and two erythroid- and deveopmental stage- specific factors ( $\varepsilon$-SSF1 and $\varepsilon$-R1 have thus been identified. We have slso analyzed the binding of nuclear protein factors prepared from three cell lines (K562, HEL and 
Raji) to these regulatory regions, and their defference to nuclear protein factors from mouse embryonic and fetal haematopoietic tissues will be discusssed.

\section{MATERIALS AND METHODS}

\section{Cell culture and preparation of nuclear extracts}

K562, HEL and Raji cells were grown in RPMI1640 medium supplemented with $10 \%$ fetal bovine serum, and the nuclear extracts were prepared from these cells according to the method of Dignam et al[7]. The protein concentration was determined by the Bradford's method[8].

\section{Mouse mating, dissection and preparation of nuclear extracts}

Mouse mating and dissection were performed by the method described by Whitelaw et al[9]. The nuclear extracts were prepared from mouse embryonic yolk sac at $d 11$ of gestation, mouse fetal liver at d 13 and d 18 of gestation, baby mouse liver of $1 \mathrm{~d}$ after birth and mouse brain as described by Gorski et al[10].

\section{Preparation of DNA probes}

The DNA fragments were prepared from $\mathrm{p} \varepsilon$ GLCAT-SV plasmid by restriction enzymes. The Xbal/HincII DNA fragment (-535 -392bp) containing the positive control region was isolated, and the HincII/BamHI DNA fragment (-392 -177bp) was prepared as a silencer region. The two fragments were 5 '-end labelled with $\Upsilon^{32}$ p-ATP respectively. These probes were used in the DNAprotein binding assays.

\section{Gel mobility shift assay}

Gel mobility shift assays were performed according to the method described by Strauss and Varshavsky[11]. The binding reaction ( $25 \mu \mathrm{l})$ contained approximately $5 \mathrm{fM}$ of end-labelled DNA probe, $3-5 \mu \mathrm{g}$ of nuclear proteins, and $1 \mu \mathrm{g}$ polyd (I-C) as a nonspecific competitor in a binding buffer (10 m $M$ Tris-HC1, pH 7.6, $100 \mathrm{~m} M \mathrm{KCl}, 1 \mathrm{~m} M \mathrm{MgC}_{2}, \operatorname{lm} M$ EDTA, $10 \mathrm{~m} M$ DTT, 4\% glycerol, and $0.1 \%$ Triton X-100). The reaction mixtures were incubated for $1 \mathrm{~h}$ on ice, and were analyzed with $4 \%$ nondenaturing polyacrylamide gel. Gel was dried and autoradiographed at $-20^{\circ} \mathrm{C}$.

\section{DNaseI footprinting assay}

DNaseI footprinting assay was carried out according to the method described by Berg et al[12]. Approximately $18 \mu \mathrm{g}$ of nuclear proteins were preincubated for $10 \mathrm{~min}$ on ice in binding buffer (10 m $M$ Tris- $\mathrm{HCl}, \mathrm{pH} 7.6,100 \mathrm{~m} M \mathrm{KC} 1,1 \mathrm{~m} M \mathrm{MgC1}_{2}, 1 \mathrm{~m} M$ EDTA, $10 \mathrm{~m} M$ DTT, $4 \%$ glycerol, and $0.1 \%$ Triton X-100), followed by the addition of DNA probe $(\sim 5 \mathrm{fM})$ and a further $20 \mathrm{~min}$ incubation. $1 \mu \mathrm{g}$ polyd (I-C) was added as a nonspecific competitor. DNaseI and $\mathrm{MgCl}_{2}(4 \mathrm{mM}$ final concentration) were added for $20 \sim 60$ sec. Digested DNA was extracted with phenol and precipitated with ethanol. The products were resolved by $8 \%$ polyacrylamide gel. A+G sequencing ladder was prepared by using Maxam and Gilbert's method[13].

\section{RESULTS}

Identification of an erythroid- and developmental stage-specific factor in the nuclear extracts prepared from mouse haemetopoietic tissues at $d 11$ and $d$ 13 of gestation binding to the positive control region upstream of the human $\varepsilon$-globin gene

Recent studies in transgenic mice have shown that the pattern of mouse $\beta$-like globin gene expression is comparable with that of human's[14]. In transgenic mice, 
DNA-protein interactions in the regulatory regions of human $\varepsilon$-globin gene

the human $\varepsilon$-globin gene starts to be expressed in embryonic yolk sac at d 9 of gestation, and is completely silenced at about d 13.5 of gestation. However, the human $r$-globin gene are expressed at embryonic and early fetal stages, but are silenced at $\mathrm{d} 16$ of gestation. The human $\beta$-globin gene expression behaves very much like the mouse $\beta^{m a j o r}$ globin gene. It is silenced at early embryonic stage, but becomes active in the early fetal liver at about d 13 of gestation and rises rapidly to maximum level at d 18 of gestation, and remains throughout the adult stage. According to these data, we chose the mouse haematopoietic tissues at $\mathrm{d} 11 \mathrm{~d} 13$ and $\mathrm{d} 18$ of gestation as experimental material representing embryonic, fetal and adult haematopoietic tissues, respectively. Baby mouse liver and adult mouse brain represent non-erythroid tissues.

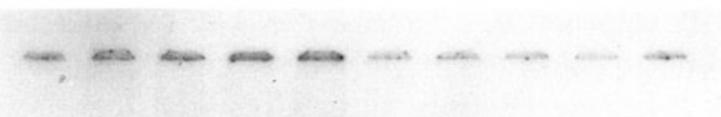

shift band -

$\varangle \varepsilon-S S F 1$

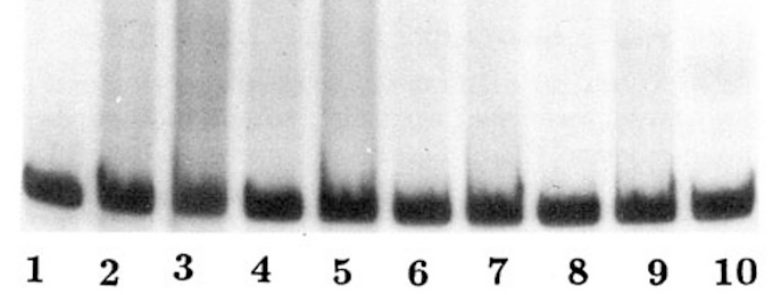

Fig 2. Gel mobility shift assays: The probe (-535 to $-392 \mathrm{bp})$ was 5 '-end labelled. Lane 1, Labelled fragment without nuclear extract. Lanes 2 and 3, labelled fragment with 3 and $5 \mu \mathrm{g}$ of nuclear extracts from mouse embryonic yolk sac at d 11 of gestation respectively. Lanes 4 and 5, Labelled fragment with 3 and $5 \mu \mathrm{g}$ of nuclear extracts from mouse fetal liver at d 13 of gestation respectively. Lanes 6 and 7, Labelled fragment with 3 and $5 \mu \mathrm{g}$ of nuclear extracts from mouse fetal liver at d 18 of gestation respectively. Lanes 8 and 9, Labelled fragment with 3 and $5 \mu \mathrm{g}$ of nuclear extracts from baby mouse liver of $1 \mathrm{~d}$ after birth respectively. Lane 10, Labelled fragment with $5 \mu \mathrm{g}$ of nuclear extracts from mouse brain.

In order to clarify the developmental regulatory mechanism of the human $\varepsilon$ globin gene expression, we have focused on examining the cis-acting elements and trans-acting factors which regulate the erythroid- and stage-specific expression of this gene.

The binding of nuclear proteins prepared from mouse haematopoietic tissues at different developmental stages to the positive control region (-535 -392bp) upstream of the human $\varepsilon$-globin gene was analyzed by gel mobility shift assays. Our results 
Yan ZJ et al.

\section{8}

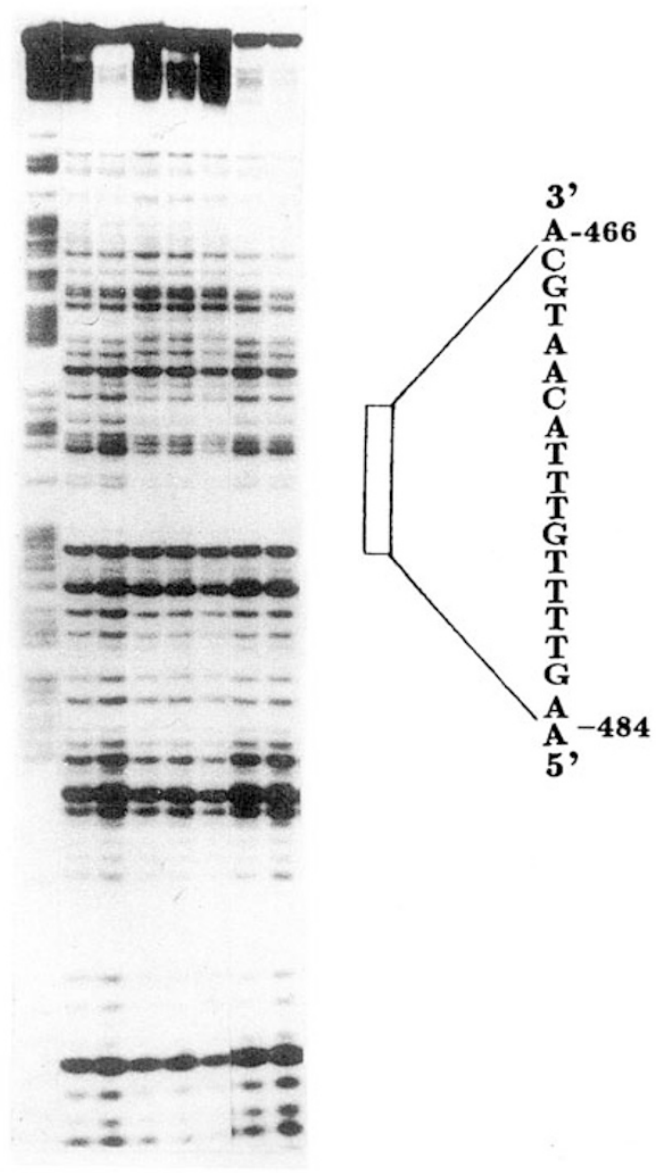

Fig 3. Identification of the protein binding sites by DNaseI footprinting assays: The probe (-535 to $-392 \mathrm{bp}$ ) was 5'-end labelled. Lane 1, A+G ladder. Lanes 2 and 3, Labelled frament without nuclear extracts $(0.5 \mu \mathrm{g}$ DNaseI for $20 \mathrm{~s}$ and $30 \mathrm{~s}$ respectively). Lanes 4, 5 and 6, Labelled fragment with $18 \mu \mathrm{g}$ of nuclear extracts from mouse fetal liver at d 13 of gestation $(0.25 \mu \mathrm{g}$ DNaseI for $20 \mathrm{~s}, 30$ and $45 \mathrm{~s}$ respectively). Lans 7 and 8 , Labelled fragment with $18 \mu \mathrm{g}$ of nuclear extracts from mouse fetal liver at d 18 of gestation ( $0.5 \mu \mathrm{g}$ DNaseI for $20 \mathrm{~s}$ and 30 s respectively).

repeatly showed that only one major shift band A (here termed $\varepsilon$-SSF1) could be detected in the nuclear extracts prepared from mouse haematopoietic tissues at $d$ 11 and $\mathrm{d} 13$ of gestation (Fig 2, lanes 2 5). However, nothing could be detected in the nuclear extracts from mouse fetal liver at $\mathrm{d} 18$ of gestation, baby mouse liver of $1 \mathrm{~d}$ after birth and mouse brain (Fig 2, lanes 6 10). Therefore, we speculate that an erythroid- and developmental stage-specific factor (termed $\varepsilon$-SSF1) might exist in the nuclear extracts from mouse haematopoietic tissues at d 11 and d 13 of ges- 
DNA-protein interactions in the regulatory regions of human $\varepsilon$-globin gene

tation. In DNaseI footprinting assays, we observed that one major region (-466 to $-484 \mathrm{bp}$ ) was protected when the nuclear extract from mouse haematopoietic tissue at $d 13$ of gestation was used (Fig 3, lanes 4 6). However this protected region could not be detected using the nuclear extract from mouse fetal liver at $\mathrm{d} 18$ of gestation (Fig 3, lanes 7 and 8). Our data suggest that this positive control region might function as an erythroid- and stage-specific regulatory element, and that the $\varepsilon$-SSF1 might be an erythroid- and stage-specific activator in activating the human $\varepsilon$-globin gene expression during early embryonic stage.

An erythroid- and developmental stage-specific factor in the nuclear extract from mouse fetal liver at $d 18$ of gestation binding to the silencer region upstream of the human $\varepsilon$-globin gene

To investigate the regulatory mechanism of the silencer (between -392 and $-177 \mathrm{bp}$ ) in silencing human $\varepsilon$-globin gene, the same analyses were carried out. Using gel

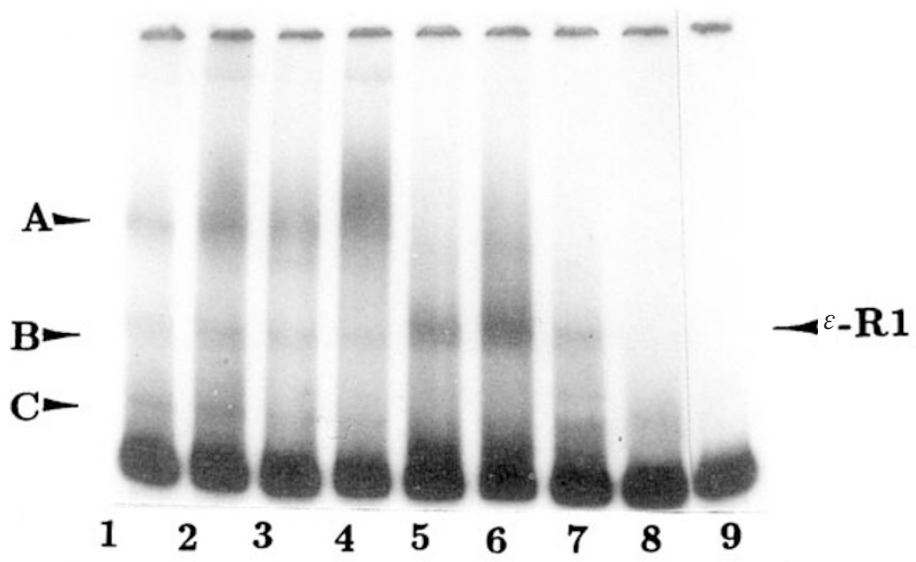

Fig 4. Nuclear proteins binding to the silencer of human $\varepsilon$-globin gene: The probe $(-392$ to $-177 \mathrm{bp}$ ) was 5 '-end labelled. Lanes 1 and 2 , Labelled fragment with 3 and $5 \mu \mathrm{g}$ of nuclear extracts from mouse embryonic yolk sac at d 11 of gestation respectively. Lanes 3 and 4, Labelled fragment with 3 and $5 \mu \mathrm{g}$ of nuclear extracts from mouse fetal liver at d 13 of gestation respectively. Lanes 5 and 6 , Labelled fragment with 3 and $5 \mu \mathrm{g}$ of nuclear extracts from mouse fetal liver at d 18 of gestation respectively. Lanes 7, Labelled fragment with $3 \mu \mathrm{g}$ of nuclear extracts from baby mouse liver of $1 \mathrm{~d}$ after birth respectively. Lane 8, Labelled fragment with $3 \mu \mathrm{g}$ of nuclear extracts from mouse brain. Lane 9, Labelled fragment without nuclear extract.

mobility shift assay, three shift bands (A, B and C) were detected with the nuclear extracts prepared from mouse haematopoietic tissues at $\mathrm{d} 11$ and $\mathrm{d} 13$ of gestation (Fig 4, lane 1 4). However, to our surprise, the amount of band B (termed $\varepsilon$ R1) seemed to rise sharply with the nuclear extract from mouse fetal liver at $d 18$ of 
gestation (Fig 4, lanes 5 and 6), and to decline dramatically with the nuclear extract from baby mouse liver of $\mathrm{d} 1$ after birth (Fig 4, lane 7). We could not detect any band in the nuclear extract from mouse brain (Fig 4, lane 8). In addition, DNase I footprinting assay was used to further detect the precise protein-binding site within the silencer region. Only one major protected region (from -278 to $-235 \mathrm{bp}$ ) could

\section{7}
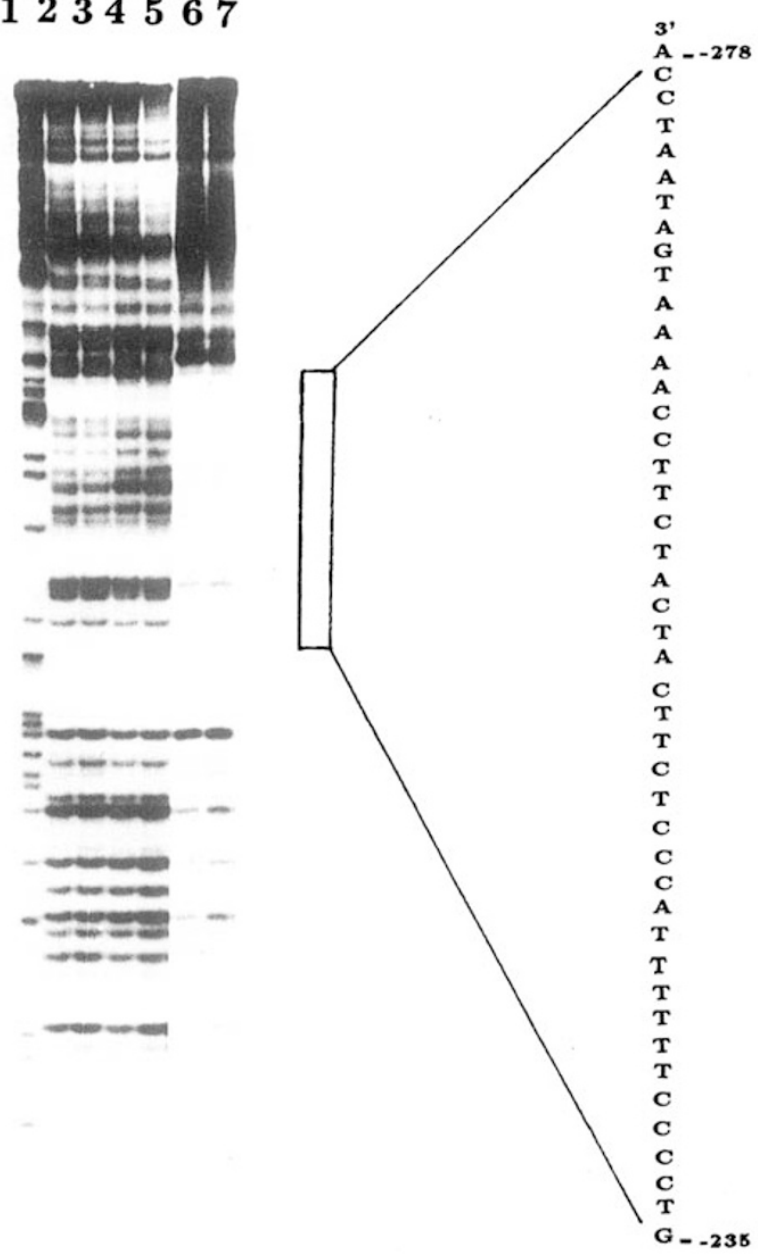

Fig 5. DNaseI footprinting assays: The probe (-392 to $-177 \mathrm{bp})$ was 5 '-end labelled. Lane 1, A+G ladder. Lanes 2 and 3, Labelled frament without nuclear extracts $(0.5 \mathrm{ug}$ DNaseI for $30 \mathrm{~s}$ and $60 \mathrm{~s}$ respectively). Lanes 4 and 5, Labelled fragment with $18 \mu \mathrm{g}$ of nuclear extracts from mouse fetal liver at d 13 of gestation $(0.25 \mu \mathrm{g}$ DNaseI for $20 \mathrm{~s}$ and $30 \mathrm{~s}$ respectively). Lans 6 and 7 , Labelled fragment with $18 \mu \mathrm{g}$ of nuclear extracts from mouse fetal liver at d 18 of gestation $(0.5 \mu \mathrm{g}$ DNaseI for $15 \mathrm{~s}$ and $30 \mathrm{~s}$ respectively). 
DNA-protein interactions in the regulatory regions of human $\varepsilon$-globin gene

be observed with the nuclear extract prepared from mouse fetal liver at $\mathrm{d} 18$ of gestation (Fig 5, lanes 6 and 7). However, this protected region could not be detected at d 13 of gestation (Fig 5, lanes 4 and 5). Our results suggest that this $\varepsilon-R 1$, existing in the nuclear extract from mouse fetal liver at $d 18$ of gestation, might be an erythroid- and developmental stage-specific repressor, and that it might function in silencing the expression of the human $\varepsilon$-globin gene during later developmental stages.

Analyses of nuclear protein factors from K562, HEL and Raji cells binding to these regulatory regions upstream of the human $\varepsilon$-globin gene

Previous studies have shown that the patterns of the human $\beta$-like globin gene expression in K562, HEL and Raji cells are different. The K562 cell, a human erythroleukemia cells line, express the human embryonic $(\varepsilon)$ and fetal $(\Upsilon)$ but not adult $(\beta)$ globin gene[15]. However, the HEL cells, also a human erythroleukemia cell line, express mainly the human fetal $(\Upsilon)$ globin gene and trace amount of the embryonic $(\varepsilon)$ globin gene, but not adult $(\beta)$ globin gene[16]. The Raji cell are of nonerythroid cell line. Therefore, these three cell lines provide an ideal model for studying the regulatory mechanism involved in the erythroid- and developmental stage- specific expression of the human $\varepsilon$-globin gene.

In order to elucidate the regulatory mechanism at a molecular level, the binding of nuclear protein factors prepared from K562, HEL and Raji cells to the positive control region (-535 -392bp) and the silencer (-392, - -177bp) upstream of the human $\varepsilon$-globin gene was analyzed. Using the positive control region $(-535 \sim 392 \mathrm{bp})$ as a probe, we found in gel mobility shift assays that the shift band $\mathrm{Kb}$, indicated by the arrow in Fig 6, was common to three cell lines. However, both shift band Ka and Kc were specific for K562 cells (Fig 6. lanes 2 and 3). The shift band E was common to HEL and Raji cells, and shift band D was specific for Raji ceils (Fig 6 lanes 4 6). DNase I footprinting assays further revealed that there were at least three protected regions specific for K562 cell (-418 to-450bp, -453 to-462bp and -466

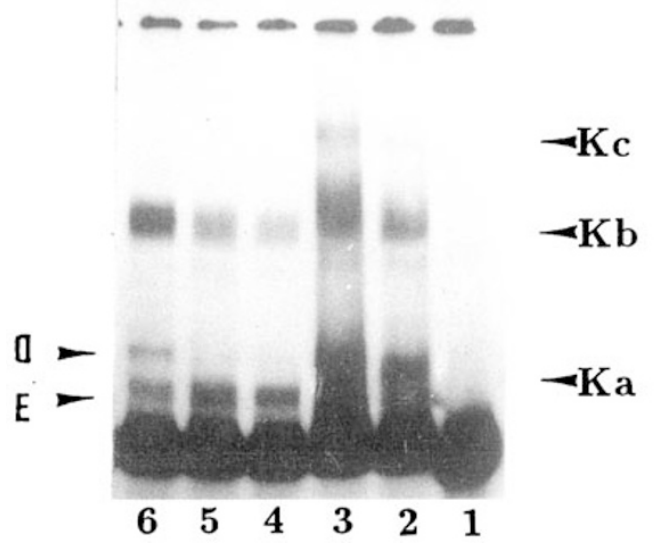

Fig 6. Bindind activities of nuclear extracts from K562, HEL and Raji cells with the DNA fragment (-535 to $-392 \mathrm{bp}$ ) upstream of human $\varepsilon$-globin gene: The probe (-535 to $-392 \mathrm{bp})$ was 5 '-end labelled. Lane 1, Labelled fragment without nuclear extract. Lanes 2 and 3 , labelled fragment with 3 and $5 \mu \mathrm{g}$ of K562 cell nuclear extracts. Lanes 4 and 5, Labelled fragment with 3 and 5 $\mu \mathrm{g}$ of HEL cell nuclear extracts. Lanes 6 , Labelled fragment with $5 \mu \mathrm{g}$ of Ragi cell nuclear extracts. 


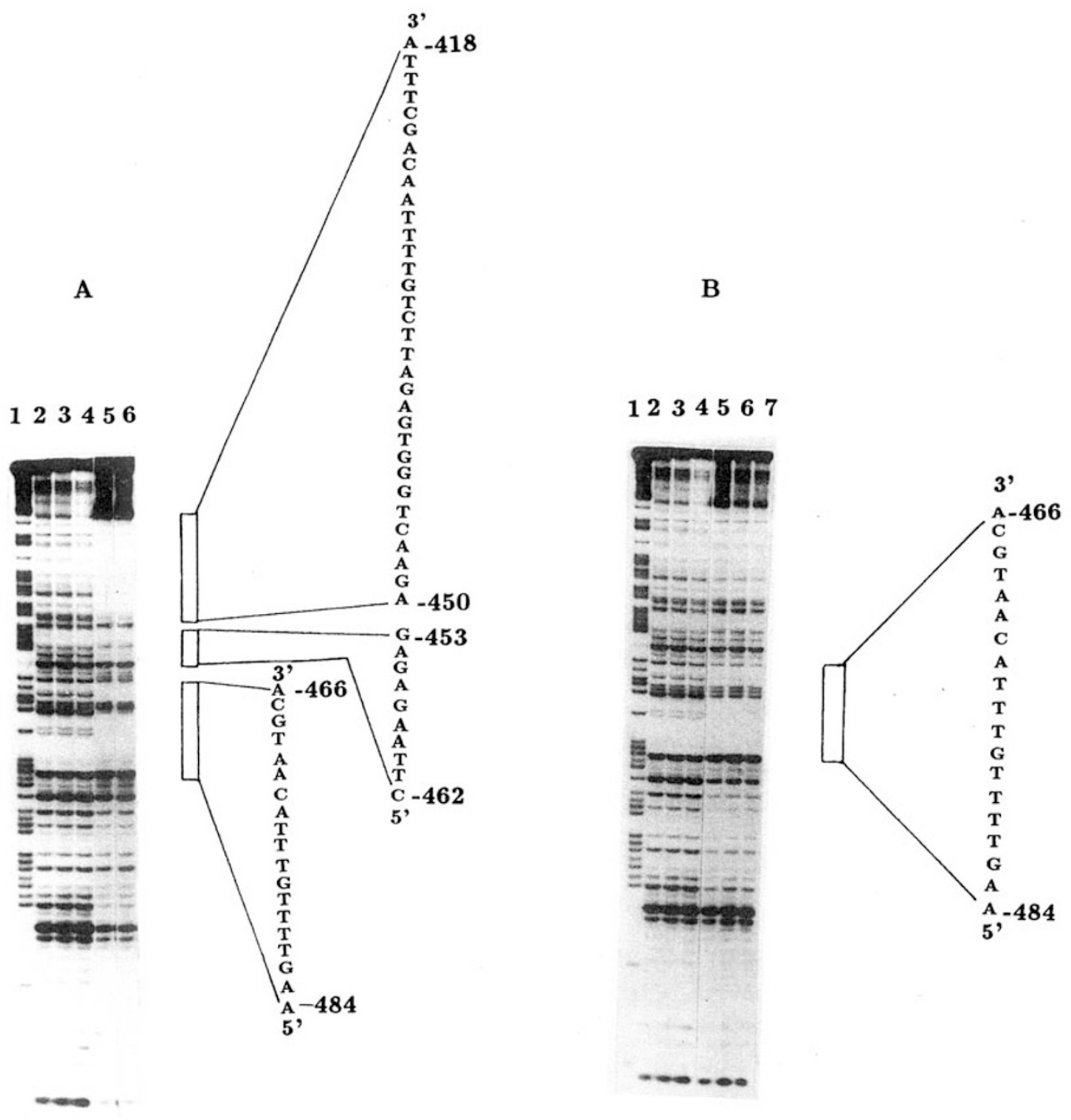

Fig 7. Localization of the cis-acting element responsible for the binding of protein factors: The probe (-535 to $-392 \mathrm{bp})$ was 5 '-end labelled. A. Lane 1, A+G ladder. Lanes 2, 3 and 4, Labelled frament without nuclear extracts $(0.5 \mu \mathrm{g}$ DNaseI for $20 \mathrm{~s}, 30 \mathrm{~s}$ and $40 \mathrm{~s}$ respectively). Lanes 5 and 6 , Labelled fragment with $18 \mu \mathrm{g}$ of nuclear extracts from K562 cells $(0.25 \mu \mathrm{g}$ DNaseI for $20 \mathrm{~s}$ and 30 respectively). B. Lane $1, \mathrm{~A}+\mathrm{G}$ ladder. Lanes 2, 3 and 4, Labelled frament without nuclear extracts $(0.5 \mu \mathrm{g}$ DNaseI for $20 \mathrm{~s}$, 30 s and 40 s respectively). Lanes 5, 6 and 7, Labelled fragment with $18 \mu \mathrm{g}$ of nuclear extracts from HEL cells $(0.25 \mu \mathrm{g}$ DNaseI for $20 \mathrm{~s}, 30$ and 45 s respectively). 
DNA-protein interactions in the regulatory regions of human $\varepsilon$-globin gene

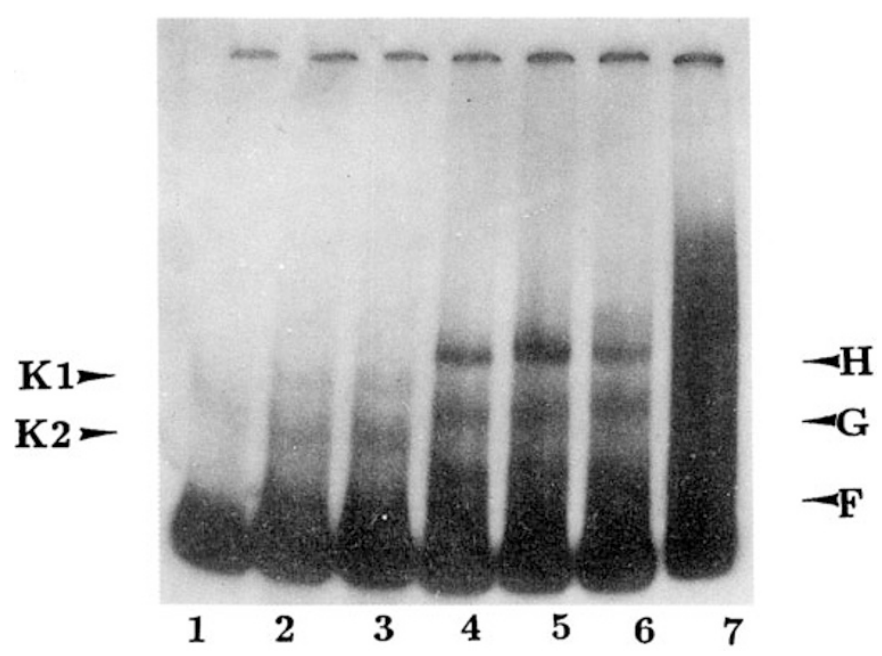

Fig 8. Binding activities of nuclear extracts from K562, HEL and Raji cells with the DNA fragment (-392 to $-177 \mathrm{bp})$ upstream of human $\varepsilon$-globin gene: The probe (-392 to $177 \mathrm{bp}$ ) was 5 '-end labelled. Lane 1 , Labelled fragment without nuclear extract. Lanes 2 and 3 , labelled fragment with 3 and $5 \mu \mathrm{g}$ of K562 cell nuclear extracts. Lanes 4 and 5 , Labelled fragment with 3 and $5 \mu \mathrm{g}$ of HEL cell nuclear extracts. Lanes 6 and 7 , Labelled fragment with 3 and $5 \mu \mathrm{g}$ of Raji cell nuclear extracts.

to $-484 \mathrm{bp}$ ) (Fig 7A, lanes 5 and 6). Our results suggest that these trans-acting factors detected in K562 cell might be, in part, responsible for the high-level expression of the human $\varepsilon$-globin gene in this embryonic erythroid cell line. Furthermore, we observed that one protected region (-466 to $-484 \mathrm{bp}$ ) was common to K562 and HEL cells (Fig 7A, lanes $5 \sim 6$ and Fig 7B, lanes $5 \sim 7$ ), and it was also very similar to that detected with the nuclear extract from mouse fetal liver at d 13 of gestation (Fig 3, lanes 4 6). Thus, we speculate that the trans-acting factor which is analogous to $\varepsilon$-SSF1 may exist in the embryonic erythroid cells (K562 and HEL cell lines).

On the other hand, the binding of nuclear protein factors prepared the from the three cell lines to the silencer region (-392 -177bp) upstream of the human $\varepsilon$-globin gene was also analyzed. In gel mobility shift assays, two shift bands (K1 and K2) could be detected with nuclear extract from K562 cells (Fig 8, lanes 2 and 3). The pattern of shift bands with nuclear extract of HEL cells was similar to that with Raji cell nuclear extract (Fig 8, lanes 4 7). However, the amount of the band $\mathrm{H}$ is predominant when HEL cell nuclear extract was used (Fig 8, lanes 4 and 5). Our data demonstrated that these trans-acting factors detected in HEL cell, which were 


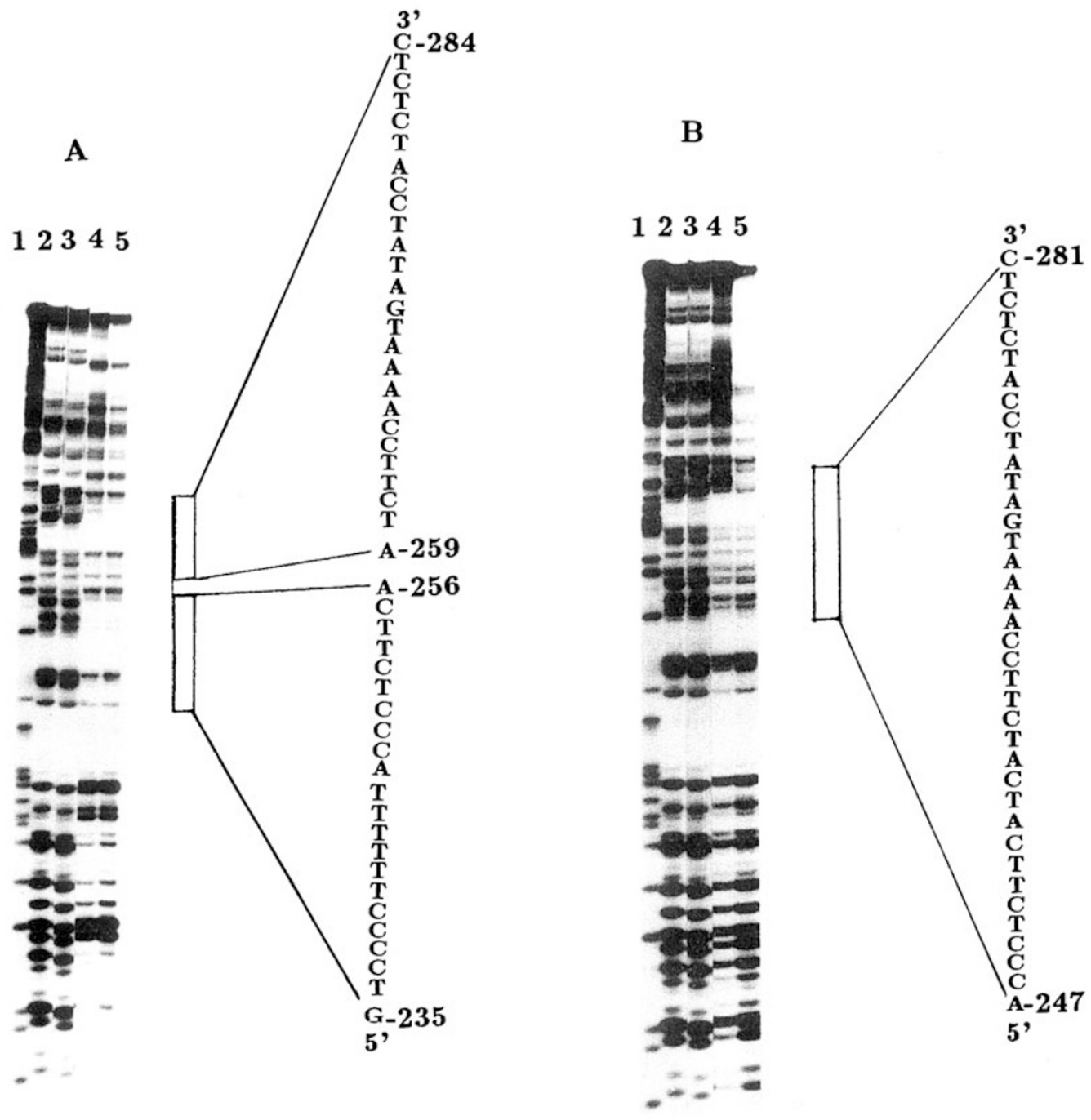

Fig 9. Determination of protected regions by DNaseI footprinting assays: The probe (-392 to $-177 \mathrm{bp}$ ) was 5 '-end labelled. A. Lane 1, A+G ladder. Lanes 2 and 3, Labelled frament without nuclear extracts $(0.5 \mu \mathrm{g}$ DNaseI for $30 \mathrm{~s}$ and $60 \mathrm{~s}$ respectively). Lanes 4 and 5 , Labelled fragment with $18 \mu \mathrm{g}$ of nuclear extracts from K562 cells $(0.5 \mu \mathrm{g}$ DNaseI for $30 \mathrm{~s}$ and $60 \mathrm{~s}$ respectively). B. Lane $1, \mathrm{~A}+\mathrm{G}$ ladder. Lanes 2 and 3. Labelled frament without nuclear extracts $(0.5 \mu \mathrm{g}$ DNaseI for $30 \mathrm{~s}$ and $60 \mathrm{~s}$ respectively). Lanes 4 and 5 , Labelled fragment with $18 \mu \mathrm{g}$ of nuclear extracts from HEL cells $(0.5 \mu \mathrm{g}$ DNaseI for $90 \mathrm{~s}$ and $1.5 \mu \mathrm{g}$ DNaseI for $60 \mathrm{~s}$ respectively).

capable of binding to this silencer, might be the cause for silencing human e-globin gene in this cell line. In addition, DNaseI footprinting assays showed that the nuclear extract from K562 cells gave two footprints (-284 to-259bp and -256 to $-235 \mathrm{bp}$ ) 
DNA-protein interactions in the regulatory regions of human $\varepsilon$-globin gene

(Fig 9A, lanes 4 and 5). However, only one protected region (-284 to $-247 \mathrm{bp}$ ) was detected using the nuclear extract from HEL cells (Fig 9B, lanes 4 and 5). Furthermore, we found that this protected region detected with HEL cell nuclear extract, in part, coincided with the binding sites for K562 cells. In addition, the binding site of the $\varepsilon-\mathrm{R} 1$ was also located partly within this region (-278 to -235bp) (Fig 5, lanes 6 and 7). Therefore, we suggest that these nuclear protein factors prepared from both human embryonic erythroid cells (K562 and HEL) and mouse fetal liver at d 18 of gestation might have a analogous DNA-binding motif within this silencer. The further characterization of these factors is still in progress.

\section{DISCUSSION}

Erythroid differentiation during development is characterized by specific pattern of globin gene expression. The study of globin gene expression has served as an important paradigm for understanding tissue-specific and developmentally regulated transcription. The human $\beta$-like globin gene cluster contains five genes $\left(\varepsilon, G_{\Upsilon}, A_{\Upsilon}\right.$, $\delta, \beta)$, which are successively expressed as the site of erythropoiesis shifts during development[1]. Expression of the individual genes of the cluster relies on a distal regulatory element, termed the locus control region (LCR), which located $6 \sim 20 \mathrm{~kb}$ upstream of the $\varepsilon$-globin gene[17]. Recent studies in transgenic mice or in differentiating embryoid bodies have shown that the human $\varepsilon$-globin gene, linked in cis with LCR sequence, is expressed in a developmentally appropriate manner which is independent of the presence of other globin genes within the locus[2, 3].

The sequence (-392 -177bp) upstream of the human $\varepsilon$-globin gene may be involved in the repression that restricts $\varepsilon$-globin gene expression to embryonic erythroid cell. Deletion of this region results in the continued expression of this gene during late fetal and adult development in transgenic mice[5]. Therefore, we suggest that activating and silencing the expression of the human $\varepsilon$-globin gene may be mediated by trans-acting factors, which appear in embryonic or adult stage, and which can specifically bind to the positive control region or silencer in the 5'-flanking sequence of the human $\varepsilon$-globin gene.

For this purpose, we have used the mouse haematopoietic system as a model to examine the developmental stage-specific protein factor(s) at different stages during development because the pattern of expression of the mouse $\beta$-like globin gene is quite analogous to that of human's[9]. During the embryonic life, at d 8 of gestation the mouse embryonic $\beta \mathrm{H} 1$ - and $\varepsilon$ Y2- globin genes begin to be expressed in yolk sac. At $d 11$ of gestation the fetal liver become the major site of erythropoiesis almost up to birth. The level of $\beta \mathrm{Hl}$-globin gene expression is highest at $\mathrm{d} 10$ and $\mathrm{d} 11$ and decline afterward, while the expression of $\varepsilon$ Y2-globin gene peaks at about $\mathrm{d} 13$ and decreases during further fetal development. The expression of the adult mouse $\beta$-globin gene peaks at about d 18. Experiments with transgenic mice have showed that the human $\varepsilon$-globin gene starts to be expressed in embryonic yolk sac at $d$ 
9 of gestation, and is completely silenced at about d 13.5 of gestation. However, the human $\Upsilon$-globin gene are expressed at embryonic and early fetal stages, but are silenced at $\mathrm{d} 16$ of gestation. The human $\beta$-globin gene expression behaves very much like the adult mouse $\beta$-globin gene. It is silenced at early embryonic stage, but becomes active in the early fetal liver at about d 13 of gestation and rises rapidly to maximum level at d 18 of gestation, and remains throughout the adult stage[14]. According to these considerations, we chose the mouse haematopoietic tissues at $d$ $11, \mathrm{~d} 13$ and d 18 of gestation as experimental material representing embryonic, fetal and adult haematopoietic tissues, respectively.

In the present study, two tissue-specific and developmental stage-specific protein factors ( $\varepsilon$-SSF1 and $\varepsilon$-R1) in the nuclear extracts prepared from mouse haematopoietic tissues at different developmental stages (at d 11, d 13 and d 18 of gestation) have been identified. Our data reveal that both positive control region (-535 $453 \mathrm{bp}$ ) and silencer (-392 -177bp) upstream of the human $\varepsilon$-globin gene may function as stage-specific regulatory elements, and these tissue-specific and developmental stage-specific protein factors ( $\varepsilon$-SSF1 and $\varepsilon-\mathrm{R} 1$ ) may be involved in activating and silencing of the human $\varepsilon$-globin gene during early embryonic development through DNA-protein interaction.

On the other hand, we have analyzed the interaction between cis-acting elements (positive control region and silencer) and trans-acting factors prepared from three cell lines (K562, HEL and Raji cells). Our data demonstrated in both gel mobility shift assays and DNaseI footprinting assays that there were at least two nuclear protein factors ( $\mathrm{Ka}$ and $\mathrm{Kc}$ ) specific for K562 cell, which could specifically bind to this positive control region. These K562 cell-specific factors might be able to partly explain the high-level expression of the human $\varepsilon$-globin gene in this cell line. In addition, three nuclear protein factors (F, G and $\mathrm{H}$ ) in HEL cell were detected, which were capable of binding to this silencer region. We suggest that these factors, especially factor $\mathrm{H}$ may be responsible for silencing the human $\varepsilon$-globin gene in this cell line.

Our data have shown that activating and silencing of the human $\varepsilon$-globin gene during early embryonic life reflects a dynamic interaction between the tissue- and developmental stage-specific trans-acting factors and multiple cis-acting elements. The results presented here may provide some insight into the molecular regulatory mechanism involved in the human $\varepsilon$-globin gene expression during early development.

\section{REFERENCES}

[1] Karlsson S, Nienhuis AW. Developmental regulation of human globin gene. Ann Rev Biochem 1985; 54:1071-108.

[2] Lindenbaum MH and Grosveld F. An in vitro globin gene switching model based on differentiated embryonic stem cell. Gene and Dev 1990; 4:2075-85.

[3] Shih DM, Wall R J, Shapiro SG, et al. A 5' control region of the human $\varepsilon$-globin gene is sufficient 


\section{DNA-protein interactions in the regulatory regions of human $\varepsilon$-globin gene}

for embryonic specificity in transgenic mice. J Biol Chem 1993; 268:3066-71.

[4] Cao S, Gutuman PG, Dave HPG, et al. Identification of a transcriptional silencer in the 5' flanking region of the $\varepsilon$ - human globin gene, Proc Natl Acad Sci 1989; 86:5306-9.

[5] Raich N, Papayannopoulous T, Stamatoyannopolos G, et al. Demonstration of a human $\varepsilon$-globin gene silencer with studies in transgenic mice. Blood 1992; 79:861-4.

[6] Wada-kiyama Y, Peters B, Noguchi CT. The $\varepsilon$-globin silencer: Characterization by in vitro transcription. J Bio Chem 1992; 267:11532-8.

[7] Dignam JD, Lebovitz RM, Roeder RG. Accurate transcription initiation by RNA polymeraseII in a soluble extract from isolated mammalian nuclei. Nuclei Acids Research 1983; 11:1475-89.

[8] Bradford MM. A rapid and sensitive method for the quantitation of microgram guantities of protein utilizing the principle of protein-dye binding. Anal Biochem 1976; 72:248-54.

[9] Whitelaw E, Tasi SF, Hogben P, et al. Regulated expression of globin chains and the erythroid transcription factor GATA-1 during erythropoiesis in the developing mouse. Mol Cell Biol 1990; 10:6596-606.

[10] Gorski K, Carneiro M, Schibler U. Tissue-specific in vitro transcription from the mouse albumin promoter. Cell 1986; 47:767-76.

[11] Strauss F, Varshavsky A. A protein binds to a satellite DNA repeat at three specific sites that would be brought into mutural proximity by DNA folding in the nucleosome. Cell 1984; 37:889-901.

[12] Berg PE, Williams DM, Qian RL, et al. A common protein to two silencers 5 ' to the human $\beta$ -globin gene. Nucleic Acids Research 1989; 17:8833-52.

[13] Maxam A, Gilbert W. Methods Enzymol, 1980; 65:499-560.

[14] Strouboulis J, Dillon N, Grosveld F. Developmental regulation of a human $\beta$-globin locus in transgenic mice. Gene and Dev 1992; 6:1857.

[15] Wada Y, Noguchi CT. In vitro differential expression of human globin gene. J Biol Chem 1988; 263:12142-6.

[16] Maxtin P, Papyannopoulous T. HEL cells: A new human erythroleukenmia cell line with spontaneous and induced globin expression. Science 1982; 216:1223-35.

[17] Grosveld F, Blom van Assandelft G, Greaves D, et al. Position independent expression of the human beta globin gene in transgenic mice. Cell 1987; 51:975-85.

Received 6-9-1996. Revised 19-11-1996. Accepted 22-11-1996. 